\title{
ARSENIC AND ZINC IN IMPOUNDMENT MATERIALS AND RELATED STREAM SEDIMENTS FROM A POLLUTED AREA IN EASTERN SLOVAKIA: DISTRIBUTION, MOBILITY, AND WATER QUALITY
}

\author{
MICHAL JANKULÁR ${ }^{1)}$, EDGAR HILLER ${ }^{1 *}$, LUBOMÍR JURKOVIČ ${ }^{1)}$, \\ VERONIKA VESELSKÁ ${ }^{1)}$, JURAJ MAJZLAN ${ }^{2)}$ \\ ${ }^{1)}$ Comenius University in Bratislava, Faculty of Natural Sciences, Department of Geochemistry, Mlynská dolina, 84215 Bratislava, \\ Slovak Republic; mailto * corresponding author: hiller@fns.uniba.sk \\ ${ }^{2)}$ Institute of Mineralogy and Geochemistry, Albert-Ludwig-University of Freiburg, Albertstrasse 23b, D-79104 Freiburg, Germany.
}

The impoundment located near the village of Poša in eastern Slovakia is a significant source of arsenic. Waters penetrating the impoundment become enriched in As and other potentially toxic elements. As a consequence, the Kyjov brook and the Ondava River have been extensively polluted by arsenic. Although, zinc is of minor environmental significance regarding pollution in the area, it was also monitored to compare its behaviour with that of arsenic. The mobility and solid-state distribution of As and $\mathrm{Zn}$ in the impoundment materials and stream sediments have been investigated using a five-step sequential extraction procedure. Moreover, to investigate the bioavailability of As and Zn, two native plant species (Typha latifolia and Phragmites australis) growing at the site were collected and analyzed. The As concentrations in representative sediment and water samples ranged from 36.28 to $3208.35 \mathrm{mg} \mathrm{kg}^{-1}$ and from 4.05 to $612.8 \mu \mathrm{g} \mathrm{l}^{-1}$, respectively, both being many times above the background levels. The $\mathrm{Zn}$ concentrations of environmental importance were found to be high only in the impoundment materials (up to $3390 \mathrm{mg} \mathrm{kg}^{-1}$ ). Although a part of As was present in a readily soluble form (6.62\%), the majority of As was mainly associated with Fe/Mn oxides $(37.30 \%)$ and residual phases $(51 \%)$. Similarly, the most dominant fractions for zinc distribution were Fe/Mn oxides (38.5\%), residual (34\%) and exchangeable (18\%). Combined results of the sequential extraction tests as well as chemical and mineralogical analysis indicated that As mobilisation potential from the sediments is likely controlled by Fe/Mn oxyhydroxide mineral phases. Plants growing in the impoundment had As concentrations 10 to 100 times higher than the same plants growing in a relatively nonpolluted area, indicating an enhanced bioavailability of arsenic in the area with high total As contents in the impoundment materials.

KEY WORDS: Arsenic, Zinc, Impoundment, Mobility, Stream Sediment, Bioavailability, Slovakia.

Michal Jankulár, Edgar Hiller, Lubomír Jurkovič, Veronika Veselská, Juraj Majzlan: ARZÉN A ZINOK V MATERIÁLOCH ODKALISKA A V RIEČNYCH SEDIMENTOCH ZO ZNEČISTENEJ OBLASTI NA VÝCHODNOM SLOVENSKU: DISTRIBÚCIA, MOBILITA A KVALITA VÔD. J. Hydrol. Hydromech., 57, 2009, 3; 46 lit., 2 obr., 4 tab.

Odkalisko, ktoré sa nachádza pri obci Poša (východné Slovensko), je významným zdrojom arzénu. Vody presakujúce cez materiál uložený v odkalisku sa tak obohacujú o As a d’alšie potenciálne toxické prvky. Dôsledkom je výrazné znečistenie toku Kyjov a rieky Ondava arzénom. Aj ked' v tejto oblasti zinok nepredstavuje až tak vel'ký environmentálny problém, je zahrnutý v tejto štúdii s ciel'om porovnat' správanie sa týchto dvoch potenciálne toxických prvkov. Na štúdium pohyblivosti a distribúcie As a Zn v materiáloch odkaliska a v riečnych sedimentoch sa použila pät'kroková sekvenčná extrakcia. Okrem toho sme skúmali bioprístupnost' As a Zn v dvoch typoch rastlín (Typha latifolia a Phragmites australis), ktoré prednostne rastú na odkalisku. Koncentrácie As v odobratých vzorkách sedimentov boli v intervale od 36,28 do $3208,35 \mathrm{mg} \mathrm{kg}^{-1}$ a v povrchových vodách od 4,05 do $612,8 \mu \mathrm{g} \mathrm{l}^{-1}$. Tieto koncentrácie sú ovel'a vyššie ako pozad'ové hodnoty pre danú oblast'. Bolo zistené, že koncentrácie Zn významné z hl'adiska znečistenia sú vysoké len v odkaliskových materiáloch (až $3390 \mathrm{mg} \mathrm{kg}^{-1}$ ). Aj ked' určitý podiel As v sedimentoch bol prítomný v l'ahko rozpustnej forme $(6,62 \%)$, väčšina As bola viazaná na oxidy Fe a Mn $(37,30 \%)$ a reziduálne fázy $(51 \%)$. Podobné to bolo pri Zn, pričom najdôležitejšie pre jeho distribúciu boli oxidy Fe a Mn (38,5\%), reziduálne fázy (34\%) a vymenitel’né pozície (18\%). Kombinované výsledky sekvenčných extrakcií ako aj chemickej a mineralogickej analýzy ukázali, že mobilizácia As zo sedimentov úzko súvisí 
s prítomnými minerálmi zo skupiny oxyhydroxidov Fe a Mn. Rastliny vyskytujúce sa na odkalisku obsahovali 10- až 100-násobne vyššie koncentrácie As ako tie isté rastliny odobraté z relatívne neznečistenej oblasti. Táto skutočnost' poukazuje na zvýšenú bioprístupnost' arzénu na skúmanom odkalisku, ktoré je typické vysokými obsahmi celkového As v uložených materiáloch.

KLÚČOVÉ SLOVÁ: arzén, zinok, odkalisko, pohyblivost', riečny sediment, bioprístupnost', Slovensko.

\section{Introduction}

During last two decades, the pollution of watercourses by toxic metals and metalloids has received increasing attention of the worldwide scientific community (Gurrieri, 1998; Bird et al., 2003; Jain et al., 2004; Lintnerová et al., 2006; Volaufová, Langhammer, 2007). Metals and metalloids are introduced into the aquatic system as a result of weathering of rocks and soils, from volcanic eruptions and a variety of human activities involving mining, metal refining processes, burning of fossil fuels, and agricultural use (Alloway, Ayres, 1993; Smedley, Kinniburgh, 2002). Metals and metalloids entering natural waters become a part of the watersediment system and their solid-state distribution into different chemical forms is controlled by a set of dynamic physico-chemical interactions and equilibria. Solid-state distribution of metals and metalloids depends on the characteristics of the sediments such as the amount and type of organic and inorganic matter, redox properties, $\mathrm{pH}$ and oxygen, being also among the most important chemical factors that affect the mobility and bioavailability of sediment-bound metals and metalloids (Chuan et al., 1996; Tack et al., 1996; Lin, Chen, 1998; Fritzsche et al. 2006). When assessing the environmental impact of contaminated sediment, the measurement of the total contents of metals and metalloids is insufficient as it does not take into consideration the mobility and bioavailability of their different chemical forms (Hickey, Kittrick, 1984; Romero et al., 2003; Pagnanelli et al., 2004).

Because of the dependence of metal(loid) mobility on the chemical form, several sequential extraction procedures have been developed to selectively remove metal(loid)s from the different chemical forms, and hence to assess the mobility and bioavailability of these elements in sediment (e.g. Hudson-Edwards et al., 2004; Vojteková, Krakovská, 2006). Sequential extraction procedures are generally based on the principle of reacting a sediment or soil with chemical solutions characterised by increasing extraction strength. Despite the well-known pitfalls of sequential extractions (readsorption, poor reproducibility, lack of selectivity)
(Rendell et al., 1980; Nirel, Morel, 1990), they are commonly used to assess the operationally defined associations, solubility and bioavailability of metals and metalloids in sediments or soils.

In this paper, arsenic pollution originating from an impoundment in an area of eastern Slovakia is investigated. The site of interest, an impoundment, is located near the village of Poša, in the upper part of the catchment of the Kyjov brook, which is a tributary of the Ondava River. The impoundment was used for the deposition of waste materials from the chemical manufacturing and ashes from the coal burning. Many of the waste materials contain significant concentrations of arsenic and metals, such as zinc. Natural weathering processes of waste materials cause the release of a certain fraction of these elements to the environment (Jurkovič et al., 2006). Therefore, the aim of this paper is to investigate arsenic pollution caused by impoundment materials in the waters and sediments of the Kyjov brook and the Ondava River. This aspect is very important when one considers that there are several inhabited areas in the studied area. Although, other metals or metalloids do not represent such an environmental "hot spot" as arsenic in the area, zinc was also selected for comparison. The emphasis of this paper was placed on the assessment of the geochemical forms of $\mathrm{As}$ and $\mathrm{Zn}$ in the sediments of the Kyjov brook and the Ondava River, and the anthropogenic materials of the impoundment using a modified Standard Material and Testing (SM\&T) sequential extraction procedure. Special aim of this paper was to assess the bioavailability of As and $\mathrm{Zn}$ by two species of native plants growing at the site. In this paper, only total arsenic was measured, the amounts of different As species that may present in the sediments and waters were not taken into account.

\section{Material and methods}

\subsection{Study area}

The studied area is situated in the eastern part of the Slovak Republic and geologically belongs to the 


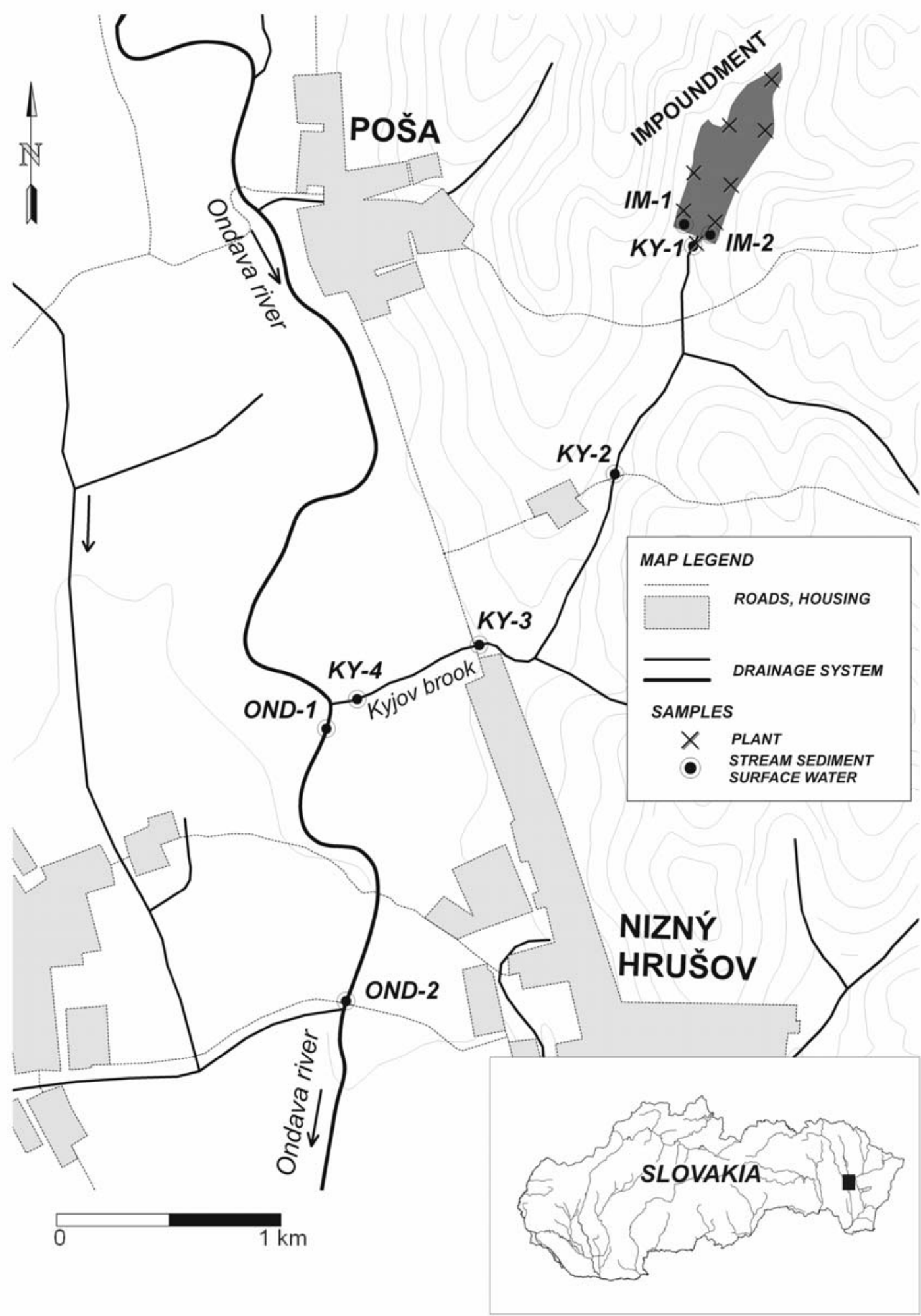

Fig. 1. Map of the studied area showing sample site locations. Obr. 1. Mapa študovanej oblasti a miesta odberu vzoriek. 
volcanic formations of the Western Carpathians Neogene basins (Fig. 1). The basement of Quarternary sediments consists of Middle Miocene sedimentary sequences of inter-arc and back-arc basins - clays and claystones, sandstones, gravels and conglomerates (Kováč, 2000; Soták et al., 2001). Neogene volcanic rocks are represented by volcanic formations with andesites, rare rhyolites, and abundant tuffaceous rocks. Quaternary fluvial sediments, loesses, loams and sands cover all older geological formations (Rudinec, 1978; Kováč, 2000).

The source of the arsenic pollution in the studied area is an impoundment located near the village of Poša, in the upper part of the catchment of the Kyjov brook (Fig. 1). The Kyjov brook flows through the impoundment and is a tributary of the Ondava River. Jurkovič et al. (2006) have shown that the Kyjov brook is severely polluted with As (mean content of total As was $1780 \mu \mathrm{g} \mathrm{l}^{-1}$ in 2005) and associated with high salinity. The Ondava River downstream of the confluence with the Kyjov brook is also contaminated with arsenic, with a mean content of $27 \mu \mathrm{g}^{-1}$ in 2005 (Jurkovič et al., 2006). Elevated As contents as compared with the mean natural background level of $2.6 \mu \mathrm{g} \mathrm{l}^{-1}$ in the area (Kordik, Slaninka, 2001) have been detected even $55 \mathrm{~km}$ downstream of the impoundment, at the confluence of the Ondava River and the Bodrog River (Jurkovič et al., 2006).

\subsection{Sampling and analytical methods}

\subsubsection{Chemical and mineralogical composition of the solid samples}

At each site, a $3 \mathrm{~kg}$ (wet weight) sediment sample was taken at $10 \mathrm{~cm}$ depth from 5-10 spots within an area of $1 \mathrm{~m}^{2}$. Overall, four stream sediment samples of the Kyjov brook at the distance of $100,1000,2000$, and $2500 \mathrm{~m}$ from the impoundment (denoted as KY-1, $-2,-3$, and -4 , respectively), two stream sediment samples of the Ondava River (OND-1, -2) and two sediment samples of the impoundment (IM-1, -2) were collected. In the laboratory, samples were air-dried, disaggregated and sieved to obtain the $<1 \mathrm{~mm}$ fraction. The $\mathrm{pH}$ of the sediments was measured in water suspensions (sediment + water ratio: $1+2.5$ ) using a WTW multi-parameter instrument (model Multi 350i). Total carbon was determined using a Leco RC-412 multiphase determinator. Organic carbon was determined using the same instrument after pretreating the sample with $0.2 \mathrm{M} \mathrm{HCl}$ to remove carbonates and the carbonate content was calculated by difference. Amorphous $\mathrm{Fe}, \mathrm{Al}$, and $\mathrm{Mn}$ oxides were measured by the ammonium oxalate method (McKeague et al., 1971). The total As, $\mathrm{Cr}, \mathrm{Pb}, \mathrm{Zn}$, $\mathrm{Al}, \mathrm{Fe}$, and $\mathrm{Mn}$ were determined by energydispersive X-ray fluorescence spectrometry (ED XRF Spectro X-lab 2000), either in sample-wax mixtures pressed into discs (As, $\mathrm{Cr}, \mathrm{Pb}, \mathrm{Zn}$ ) or after melting the sample with lithium tetraborate (Al, Fe, $\mathrm{Mn})$. Antimony and $\mathrm{Cd}$ were determined after a digestion with a $\mathrm{HF} / \mathrm{HNO}_{3} / \mathrm{HCl}$ acid mixture using atomic absorption spectrometry (AAS) equipped with a hydride generation system and AAS (Varian AAS-220), respectively. Quality of the total sample analysis was checked with GBW07311 reference material (stream sediment) containing $118 \mathrm{mg} \mathrm{kg}^{-1}$ of total As. The measured value $\left(113 \pm 7 \mathrm{mg} \mathrm{kg}^{-1}\right.$; $n=3$ ) was not significantly different from the certified value.

Mineralogical analysis of the selected sediment samples was performed by X-ray diffraction with a Bruker AXS D8 Advance diffractometer equipped with a $\mathrm{Cu}-K_{\alpha}$ radiation source and a diffractedbeam graphite monochromator. Further information concerning mineral chemistry and textural features was obtained with a scanning electron microscope (model Jeol JSM-840) and electron microprobe (Cameca SX-100) equipped with an energydispersive detector (KEVEX DELTA IV+).

\subsubsection{Chemical composition of the water samples}

In conjunction with the sediment sampling, water samples at each site were also collected. The $\mathrm{pH}$ and conductivity were measured in situ. Dissolved organic carbon (DOC) in the water samples was estimated by a Leco RC-412 multiphase determinator. Water samples were filtered through a $0.4 \mu \mathrm{m}$ filter and acidified with $\mathrm{HNO}_{3}(1 \% \mathrm{v} / \mathrm{v}$, suprapure grade) for metal analyses. Selected metals were analyzed by a Varian 220 atomic absorption spectrometer. An aliquot filtered was used for the determination of total As and Sb by AAS-HG (Varian-AAS 220) equipped with a hydride generation system (VGA 76). Instrumental accuracy and precision were monitored using blind duplicates and found to be within the range of $\pm 10 \%$ or better. 


\subsubsection{Sequential extraction}

To selectively remove arsenic and zinc from the different geochemical forms of the sediment samples, a modified version of the original SM\&T sequential extraction procedure according to Quevauviller (1998) was used. Details are presented in Tab. 1. All materials and flasks used were immersed in $50 \%(\mathrm{v}: \mathrm{v})$ analytical grade $\mathrm{HNO}_{3}$ overnight and then extensively washed with deionized water before use. Total arsenic and zinc in the ex- tracts was analyzed by the same analytical method as described above. In order to monitor the accuracy of the procedure, summed arsenic and zinc concentrations in the 5 steps were compared with the values obtained for total arsenic and zinc concentrations by ED XRF method. Recovery rates for the 5 steps of the sequential extraction procedure were $71-126 \%$ and $67-97 \%$ for arsenic and zinc, respectively. The sequential extraction procedure was performed in triplicate.

$\mathrm{T} \mathrm{a} \mathrm{b} l \mathrm{e}$ 1. Extractants and conditions used to sequentially extract arsenic and zinc from sediment samples.

T a b u l'k a 1. Extrakčné činidlá a podmienky použité na sekvenčnú extrakciu arzénu a zinku zo vzoriek sedimentov.

\begin{tabular}{|c|c|}
\hline Extractants and conditions & Fraction removed \\
\hline \multirow{3}{*}{\multicolumn{2}{|c|}{$\begin{array}{l}\text { 1. Place } 1 \mathrm{~g} \text { air-dried sample }+50 \mathrm{ml} \text { deionized and distilled water in polyethylene } \\
\text { tube, shake for } 16 \mathrm{~h} \text {, centrifuge at } 4000 \mathrm{rpm} \text { for } 20 \mathrm{~min} \text {. } \\
\text { 2. Add } 40 \mathrm{ml} 0.11 \mathrm{M} \text { acetic acid, shake for } 16 \mathrm{~h} \text {, and centrifuge } \\
\text { 3. Wash sample from (2) with } 20 \mathrm{ml} \text { deionized and distilled } \mathrm{H}_{2} \mathrm{O} \text {, then add } 40 \mathrm{ml} \text { of } 0.1 \\
M \text { hydroxylamine hydrochloride acidified to } \mathrm{pH} 2 \text {, shake for } 16 \mathrm{~h} \text {, and centrifuge. }\end{array}$}} \\
\hline & \\
\hline & \\
\hline \multirow{2}{*}{\multicolumn{2}{|c|}{ 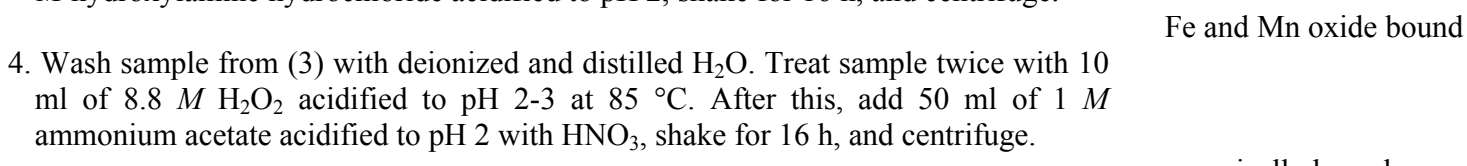 }} \\
\hline & \\
\hline & organically bound \\
\hline $\begin{array}{l}\text { 5. Wash sample from (4) with deionized and distilled } \mathrm{H}_{2} \mathrm{O} \text {. Digest with } \mathrm{HCl} / \mathrm{HNO}_{3} \text { acid } \\
\text { mixture for } 16 \mathrm{~h} \text { at } 100{ }^{\circ} \mathrm{C} \text {, and centrifuge. }\end{array}$ & residual \\
\hline
\end{tabular}

\subsubsection{Plant samples}

In addition to sediment and water sampling, the plant species Typha latifolia and Phragmites australis were collected to determine the bioavailability of arsenic and zinc. These are the dominant species overgrowing the impoundment. Plants were amassed from seven sites on the impoundment and from one site at the effluence of the Kyjov brook from the impoundment (Fig. 1). The sampling for both plants was repeated three times in an area of $1 \mathrm{~m}^{2}$ around each sampling point and the samples were mixed to obtain a homogeneous sample. Roots and shoots were analyzed for arsenic and zinc content. In the laboratory, the plants were rinsed with deionized water, air-dried at room temperature, powdered in a stainless-steel mill to obtain a homogeneous sample, and prepared for analysis. Samples of plants $(0.5 \mathrm{~g})$ were digested with water, hydrogen peroxide and concentrated $\mathrm{HNO}_{3}$ using a microwave oven CEM Star 2 Plus. After cooling, the digests were enriched with concentrated $\mathrm{H}_{2} \mathrm{SO}_{4}$. The digests were then heated at $150{ }^{\circ} \mathrm{C}$ for $2-3$ hours and concentrated by evaporation to approximately $0.5 \mathrm{ml}$. Arsenic and zinc con- centrations in the solutions were measured by AASHG and AAS, respectively.

\section{Results and discussion}

\subsection{Sediment characterisation}

The impoundment sediment materials (IM-1, IM2) and the sediment most proximal to the impoundment (KY-1) have very high organic carbon content (Tab. 2). This could be attributed to the fact that the impoundment was used for the deposition of fly-ash and chemical manufacturing waste. Mineralogical composition of the impoundment materials IM-1, -2 and sediment KY-1 was distinctly different from that of the other sediment samples. Macroscopic and microscopic inspection of the impoundment materials and sediment most proximal to the impoundment showed a dominance of vitreous materials, organic matter, and mullite. Additionally, SEM analysis revealed the presence of iron oxides (possibly $\mathrm{Fe}_{3} \mathrm{O}_{4}, \mathrm{FeO}$, or $\mathrm{Fe}_{2} \mathrm{O}_{3}$ ) and metallic iron. Quartz $\left(\mathrm{SiO}_{2}\right)$ and calcite $\left(\mathrm{CaCO}_{3}\right)$ are also abundant minerals in these samples. Further- 
Arsenic and zinc in impoundment materials and related stream sediments from a polluted area in Eastern Slovakia: distribution,...

T a b l e 2. Physico-chemical characteristics and mineralogical composition of the analyzed sediment samples.

T a b u l'k a 2. Fyzikálno-chemické vlastnosti a mineralogické zloženie skúmaných vzoriek sedimentov.

\begin{tabular}{|c|c|c|c|c|c|c|c|c|}
\hline & \multicolumn{2}{|c|}{ Impoundment } & \multicolumn{4}{|c|}{ Kyjov brook } & \multicolumn{2}{|c|}{ Ondava River } \\
\hline & IM-1 & IM-2 & KY-1 & KY-2 & KY-3 & KY-4 & OND-1 & OND-2 \\
\hline $\mathrm{TOC}^{\mathrm{a})}[\%]$ & 37.10 & 22.80 & 9.42 & 0.45 & 0.27 & 0.48 & 0.32 & n.d. \\
\hline $\mathrm{CC}^{\mathrm{b})}[\%]$ & 0.00 & 2.33 & 1.08 & 0.13 & 0.06 & 0.04 & 0.10 & n.d. \\
\hline $\mathrm{pH}\left(\mathrm{H}_{2} \mathrm{O}\right)$ & 8.54 & 7.29 & 7.31 & 7.02 & 7.31 & 7.35 & 7.23 & 7.49 \\
\hline $\mathrm{Fe}_{\mathrm{OX}}{ }^{\mathrm{c})}\left[\mathrm{g} \mathrm{kg}^{-1}\right]$ & 10.44 & 10.76 & 47.40 & 4.04 & 5.48 & 3.82 & 3.30 & 4.28 \\
\hline $\mathrm{Mn}_{\mathrm{OX}}{ }^{\mathrm{c}}\left[\mathrm{g} \mathrm{kg}^{-1}\right]$ & 0.32 & 2.29 & 4.42 & 0.44 & 0.70 & 0.60 & 0.55 & 0.53 \\
\hline $\mathrm{Al}_{\mathrm{OX}}^{\mathrm{c})}\left[\mathrm{g} \mathrm{kg}^{-1}\right]$ & 0.81 & 1.24 & 5.68 & 0.45 & 0.66 & 0.59 & 0.55 & 0.40 \\
\hline \multicolumn{9}{|c|}{ Total content of elements } \\
\hline As $\left[\mathrm{mg} \mathrm{kg}^{-1}\right]$ & 1762.75 & 611.38 & 3208.35 & 159.74 & 237.32 & 192.92 & 67.99 & 36.28 \\
\hline $\mathrm{Cd}\left[\mathrm{mg} \mathrm{kg}^{-1}\right]$ & 0.85 & 4.00 & 1.20 & 0.20 & 0.19 & 0.26 & 0.39 & 0.72 \\
\hline $\mathrm{Cr}\left[\mathrm{mg} \mathrm{kg}^{-1}\right]$ & 117.32 & 120.56 & 74.37 & 47.60 & 55.34 & 61.16 & 48.46 & 54.53 \\
\hline $\mathrm{Pb}\left[\mathrm{mg} \mathrm{kg}^{-1}\right]$ & 30.57 & 45.36 & 28.44 & 12.26 & 14.20 & 17.99 & 13.19 & 15.79 \\
\hline $\mathrm{Sb}\left[\mathrm{mg} \mathrm{kg}^{-1}\right]$ & 9.42 & 12.91 & 19.22 & 0.90 & 1.62 & 1.29 & 0.78 & 0.80 \\
\hline $\mathrm{Zn}\left[\mathrm{mg} \mathrm{kg}^{-1}\right]$ & 100.85 & 3389.67 & 992.48 & 65.76 & 67.57 & 71.21 & 59.90 & 65.72 \\
\hline $\mathrm{Al}\left[\mathrm{g} \mathrm{kg}^{-1}\right]$ & 107.50 & 14.17 & 30.90 & 43.60 & 44.20 & 63.69 & 55.75 & 46.07 \\
\hline $\mathrm{Fe}\left[\mathrm{g} \mathrm{kg}^{-1}\right]$ & 88.45 & 15.29 & 100.26 & 18.77 & 22.80 & 25.51 & 18.30 & 23.35 \\
\hline $\operatorname{Mn}\left[\mathrm{g} \mathrm{kg}^{-1}\right]$ & 1.46 & 3.03 & 10.05 & 0.68 & 0.99 & 0.95 & 0.55 & 0.71 \\
\hline \multicolumn{9}{|c|}{ Mineralogical composition ${ }^{\mathrm{d})}$} \\
\hline & \multicolumn{2}{|c|}{$\begin{array}{l}\text { Qz, Cc, Fe-Ox, Vp, } \\
\text { Ml, OrgM, Gy, B, } \\
\text { St, Sp, NiCuSl, }\end{array}$} & $\begin{array}{l}\text { Qz, Cc, Fe- } \\
\text { Ox, Fe, Vp, } \\
\text { Ml, Gy, B, } \\
\text { OrgM, St, } \\
\text { NiCuSl }\end{array}$ & \multicolumn{3}{|c|}{$\mathrm{Qz}, \mathrm{Fs}, \mathrm{M} / \mathrm{Ill}, \mathrm{Cc}, \mathrm{S}, \mathrm{Cl}, \mathrm{Kl}, \mathrm{Fe}-\mathrm{Ox}$} & \multicolumn{2}{|c|}{$\begin{array}{l}\text { Qz, Fs, M/Ill, Cc, S, } \\
\text { Fe-Ox }\end{array}$} \\
\hline
\end{tabular}

a) Total organic carbon; ${ }^{\mathrm{b})}$ Carbonate content; ${ }^{\mathrm{c})} \mathrm{Ammonium}-\mathrm{oxalate}$ extractable $\mathrm{Fe}, \mathrm{Mn}$, and $\mathrm{Al}$; ${ }^{\mathrm{d})}$ Mineral abbreviations: $\mathrm{B}$ (barite), $\mathrm{Cc}$ (calcite), $\mathrm{Cl}$ (chlorite), Fe-Ox (Fe oxides, mainly amorphous), Fs (feldspars), Gy (gypsum), Kl (kaolinite), M/Ill (muscovite/illite), Ml (mullite - product of the high-temperature treatment of clays), NiCuSl (Ni and Cu sulphides), OrgM (organic matter matrix), Qz (quartz), S (smectites), Sp (sphalerite), St (stibnite), Vp (vitreous phases); n.d.: not determined

more, we found accessory amounts of sulphides and sulphates such as sphalerite $(\mathrm{ZnS})$, stibnite $\left(\mathrm{Sb}_{2} \mathrm{~S}_{3}\right), \mathrm{Cu}$ and $\mathrm{Ni}$ sulphides, gypsum $\left(\mathrm{CaSO}_{4} \cdot 2 \mathrm{H}_{2} \mathrm{O}\right)$, and barite $\left(\mathrm{BaSO}_{4}\right)$.

More than $1 \mathrm{~km}$ downstream of the impoundment, the sediments (KY-2 - KY-4) were composed predominantly of quartz, phyllosilicates (mainly illite/muscovite and smectite), feldspars, minor calcite, and amorphous or poorly-crystallised Fe-oxides (Tab. 2). Thus, the mineral composition of the stream sediments is controlled to a great extent by the source-area lithology, but not by the phases occurring in the impoundment material.

\subsection{Arsenic and zinc in stream sediments and impoundment materials}

The total As content in the stream sediments and impoundment materials is shown in Tab. 2. These values were 5- to 400-times higher than the natural background level for this element in the area of study ( $8 \mathrm{mg} \mathrm{kg}^{-1}$; Jurkovič et al., 2006). The sedi- ment samples had much higher As contents than the limit value of $20 \mathrm{mg} \mathrm{kg}^{-1}$ for bottom sediments given by the legislation No. 188/2003, the Ministry of Agriculture SR (www.zbierka.sk). At seven sampling sites, arsenic is also present at concentrations higher than the intervention threshold $(55 \mathrm{mg}$ $\mathrm{kg}^{-1}$ ) given by the Dutch guidelines (Visser, 1995; $V R O M, 2000)$. Sites with arsenic concentrations exceeding the intervention threshold can be considered seriously contaminated and pose a threat to the functional properties of human, plant and animal life $(V R O M, 2000)$. At the site farthest from the impoundment (OND-2), arsenic concentration lies between Dutch target $\left(29 \mathrm{mg} \mathrm{kg}^{-1}\right)$ and intervention value $\left(55 \mathrm{mg} \mathrm{kg}^{-1}\right)$. Arsenic concentrations in the Ondava River are much lower than those in the Kyjov brook, most probably as a result of dilution by inputs of a cleaner sediment from bank erosion and relatively non-polluted upper part of the Ondava River. Significant correlation existed between total As content and total Fe $\left(r^{2}=0.888, p<0.001\right)$, $\mathrm{NH}_{4}$-oxalate extractable Fe $\left(r^{2}=0.864, p<0.001\right)$, 
total Mn $\left(r^{2}=0.794, p<0.01\right), \mathrm{NH}_{4}$-oxalate extractable $\mathrm{Mn}\left(r^{2}=0.604, p<0.05\right)$ and $\mathrm{NH}_{4}$-oxalate extractable $\mathrm{Al}\left(r^{2}=0.796, p<0.01\right)$. These results indicate that hydrous $\mathrm{Fe}, \mathrm{Mn}$ and $\mathrm{Al}$ oxides play a major role in the retention of arsenic in the sediments, consistently with the previous studies (Matera, Hecho, 2001; Cai et al., 2002; Chen et al., 2002; Fritzsche et al., 2006). There was also a significant correlation $\left(r^{2}=0.789, p<0.01\right)$ between the concentration of As and that of Sb. This is not surprising given that the geochemical behaviour of As and Sb is rather similar (Crecelius et al., 1975; Tighe et al., 2005).

The $\mathrm{Zn}$ contents at site IM-2 exceeded the limit value of $2500 \mathrm{mg} \mathrm{kg}^{-1}$ according to the legislation No. 188/2003, the Ministry of Agriculture SR (www.zbierka.sk) and were below this value at the other sites. Only at two sites (IM-2 and KY-1), Zn was present at concentrations greatly exceeding the intervention threshold of $720 \mathrm{mg} \mathrm{kg}^{-1}$ for this element (VROM, 2000). These high $\mathrm{Zn}$ concentrations relative to intervention threshold are likely due to the presence of $\mathrm{Zn}$ sulphide and other metal sulphides in the two samples (Tab. 2). Downstream of the impoundment, the $\mathrm{Zn}$ concentrations decreased sharply being lower than its respective Dutch target value of $140 \mathrm{mg} \mathrm{kg}^{-1}$ (VROM, 2000). This indicates that $\mathrm{Zn}$ transport in its dissolved state is reduced likely due to the neutral $\mathrm{pH}$ of surface waters, which will promote adsorption rather than dissolution of $\mathrm{Zn}$ ions. Total zinc concentrations in the solids correlated significantly only with the cadmium concentrations $\left(r^{2}=0.963, p<0.001\right)$, highlighting their similar geochemical behaviours (Fergusson, 1990).

\subsection{Water quality}

The physico-chemical parameters and the inorganic components in the surface waters of the studied area are summarized in Tab. 3. In comparison with the Ondava River and the reference streams in the studied area (Jurkovič et al., 2006), the water in the impoundment and the Kyjov brook has elevated total dissolved solids (TDS) (Tab. 3). A typical feature of these waters is the high As concentration greatly exceeding the As limit $\left(100 \mu \mathrm{g}^{-1}\right)$ for the fifth quality class of surface waters (the worst quality) as defined by the Slovak authorities (Anon, 2005). The estimated mean of total As in stream waters at a world scale is only $4 \mu \mathrm{g} \mathrm{l}^{-1}$ (Reimann, Caritat, 1998) and regional background mean value is $2.6 \mu \mathrm{g}^{-1}$ (Jurkovic et al., 2006). The waters have also elevated concentrations of dissolved organic carbon (DOC) (Tab. 3). At the time of sampling (June 21, 2006), the As concentration in the water of the Ondava River was approximately 110 times lower than that in the Kyjov brook. This is due to the mixing of the highly polluted waters of the Kyjov brook with relatively cleaner surface water from the upper part of the Ondava River. The As concentration in a water sample of the Ondava River collected $100 \mathrm{~m}$ upstream of the confluence with the Kyjov brook was $2.2 \mu \mathrm{g}^{-1}$. Previously, data from the national monitoring programme during 1995-2004 showed seasonal variability of the As concentrations in the Ondava River downstream of the confluence with the Kyjov brook with the greatest As concentrations (up to $210 \mu \mathrm{g}^{-1}$ ) during snow melting in spring (Jurkovič et al., 2006). The data of Jurkovič et al. (2006) and Hiller et al. (2007) also suggest that As-enriched waters are related to leaching of As-bearing waste materials stored in the impoundment. In most cases, zinc concentrations in the surface waters investigated were lower than its limit of $20 \mu \mathrm{g} \mathrm{l}^{-1}$ for the first quality class of surface waters.

\subsection{Geochemical forms of arsenic and zinc and their environmental significance}

Arsenic in the impoundment sediments and the stream sediment close to the impoundment is largely associated with the residual fractions (69\%) and the Fe and Mn oxides (23\%) (Fig. 2). The concentration of arsenic in the residual fraction of these samples probably reflects As in vitreous phases, mullite, and other unidentified phases that were not susceptible to decomposition by extractants intended to dissolve carbonates, oxides, organic matter and sulphides. At sites downstream of the impoundment, $46 \%$ of As was extracted in step 3, thus suggesting adsorption to $\mathrm{Fe}$ and $\mathrm{Mn}$ oxides. Generally, the percentage of As adsorbed to $\mathrm{Fe}$ and $\mathrm{Mn}$ oxides increases downstream from the impoundment (Fig. 2). This strong association of arsenic with $\mathrm{Fe}$ and $\mathrm{Mn}$ oxides is consistent with the existing relationship between total As concentration and total Fe and $\mathrm{Mn}$, as described above.

Water soluble and exchangeable arsenic are of the greatest interest since these fractions are considered to be the most available to biota and most easily leached to groundwater. All sediment samples had relatively elevated water soluble As con- 
$\mathrm{T}$ a b 1 e 3. Physico-chemical parameters and concentrations of As and $\mathrm{Zn}$ in surface waters from the impoundment, the Kyjov brook and the Ondava River.

T a b u l'k a 3. Fyzikálno-chemické ukazovatele a koncentrácie As a Zn v povrchových vodách z odkaliska potoka Kyjov a rieky Ondava.

\begin{tabular}{|c|c|c|c|c|c|c|c|c|}
\hline & \multicolumn{2}{|c|}{ Impoundment } & \multicolumn{4}{|c|}{ Kyjov brook } & \multicolumn{2}{|c|}{ Ondava River } \\
\hline & IM-1 & IM-2 & $\mathrm{KY}-1$ & $\mathrm{KY}-2$ & $\mathrm{KY}-3$ & KY-4 & OND-1 & OND-2 \\
\hline $\mathrm{pH}$ & 8.41 & 7.53 & 7.97 & 7.66 & 7.74 & 7.98 & 7.62 & 7.05 \\
\hline $\mathrm{DOC}^{\mathrm{a})}\left[\mathrm{mg} \mathrm{l}^{-1}\right]$ & n.d. & 32.4 & 33.8 & 29.7 & 29.0 & 30.2 & 5.7 & 5.5 \\
\hline Cond. ${ }^{b)}\left[\mu \mathrm{S} \mathrm{cm}^{-1}\right]$ & 1633 & 1535 & 1374 & 1312 & 1276 & 1260 & 494 & 521 \\
\hline $\operatorname{TDS}^{\mathrm{c})}\left[\mathrm{mg} \mathrm{l}^{-1}\right]$ & n.d. & 907 & 1103.5 & 1019 & 997.5 & 969.3 & 412.1 & 412.9 \\
\hline As $\left[\mu \mathrm{gl}^{-1}\right]$ & 450.6 & 612.8 & 450.8 & 466.7 & 393.5 & 449.9 & 4.27 & 4.05 \\
\hline $\mathrm{Sb}\left[\mu \mathrm{g} \mathrm{l}^{-1}\right]$ & n.d. & 24.0 & 36.0 & 17.0 & 39.0 & 60.0 & 2.0 & 3.0 \\
\hline $\mathrm{Zn}\left[\mu \mathrm{g}^{-1}\right]$ & n.d. & 10.5 & 26.8 & 17.0 & 16.0 & 16.3 & 1.0 & 2.0 \\
\hline $\mathrm{Fe}\left[\mu \mathrm{g} \mathrm{l}^{-1}\right]$ & 318 & 203 & 779 & 691 & 605 & 663 & 607 & 622 \\
\hline $\operatorname{Mn}\left[\mu \mathrm{g}^{-1}\right]$ & 2650 & 350 & 3115 & 2964 & 2830 & 2726 & 132 & 152 \\
\hline
\end{tabular}

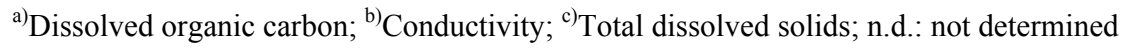

centrations (0.83-98.50 mg kg-1) and accounted for between $0.76 \%$ and $9.81 \%$ of total As content in stream sediments and impoundment materials). These values are much higher than those reported in the studies of Kavanagh et al. (1997) and Ganne et al. (2006) in mine wastes and soils, but comparable with the studies of $X u$, Thornton (1985) and Cao, Ma (2004). Arsenic contents associated with $\mathrm{Fe}$ and $\mathrm{Mn}$ oxides (18.67-935 mg kg${ }^{-1}$ ) showed positive correlation with those of water soluble As $\left(r^{2}=0.929, p<0.001\right)$, suggesting that the $\mathrm{Fe}$ and Mn oxides are the source of the more mobile and bioavailable As in stream sediments and impoundment materials. According to Bird et al. (2003), potential environmental risk resulting from heavy metals and As in sediments should be evaluated by comparing element concentrations in the most mobile fractions, i.e. in the first 2 steps of the sequential extraction procedure with target or intervention values. In this study, summed arsenic concentrations in the first 2 steps $\left(37-116 \mathrm{mg} \mathrm{kg}^{-1}\right)$ exceed Dutch intervention and target values at 2 sampling sites in the impoundment and 1 site in the Kyjov brook close to the impoundment. Therefore, arsenic at these sites may be environmentally significant with respect to bioavailability, ecotoxicity and chemical mobilisation. For the remaining sites, arsenic concentrations in the first 2 steps fall below Dutch target value. In conclusion, the sum of As concentrations in the most mobile fractions of the sequential extraction procedure is significantly correlated with its total content $\left(r^{2}=0.858, p<\right.$ $<0.01$ ), regardless of the sample nature (impoundment material, stream sediments of the Kyjov brook and the Ondava River).
Zinc is unevenly distributed among the solids investigated, although some general features could be observed. Zinc distribution is dominated by the residual fraction $(54 \%)$ in the impoundment sediment IM-1, while the nonresidual fractions prevail in the IM-2 (Fig. 2). This is a symptom of heterogeneous nature of the waste materials stored in the impoundment. Besides the residual fraction (mean $34 \%$ of total $\mathrm{Zn}$ content), the most dominant fractions are $\mathrm{Fe} / \mathrm{Mn}$ oxide and exchangeable fractions with mean values of 38.5 and $18 \%$, respectively. In agreement with these results, various studies also reported the dominance of the Fe/Mn oxide- and exchangeable-bound Zn (Ramos et al., 1994; Adamiec, Helios-Rybicka, 2002; Bird et al., 2003; Sakan et al., 2007). Relatively mobile and bioavailable first two fractions represent $6.73-53.53 \%$ of the total $\mathrm{Zn}$ contents with a mean value of $20.2 \%$. However, when these relatively high rates are expressed in concentration levels $\left(6.8-1814 \mathrm{mg} \mathrm{kg}^{-1}\right)$, they do not exceed limit values for $\mathrm{Zn}$ given by the Dutch guidelines in most of the sites, except for the site IM-2 with the high total $\mathrm{Zn}$ content (Tab. 2). As in the case of arsenic, $\mathrm{Zn}$ concentrations in the first two fractions correlated strongly with its total content $\left(r^{2}=0.975, p<0.001\right)$.

\subsection{Arsenic and zinc in plants}

Typha latifolia and Phragmites australis as the most dominant plant species overgrowing the impoundment were analyzed for As and $\mathrm{Zn}$ concentrations. The concentrations of As in the roots and shoots of Typha latifolia varied greatly from 18.73 to $976 \mathrm{mg} \mathrm{kg}^{-1}$ and from 0.42 to $635 \mathrm{mg} \mathrm{kg}^{-1}$, re- 

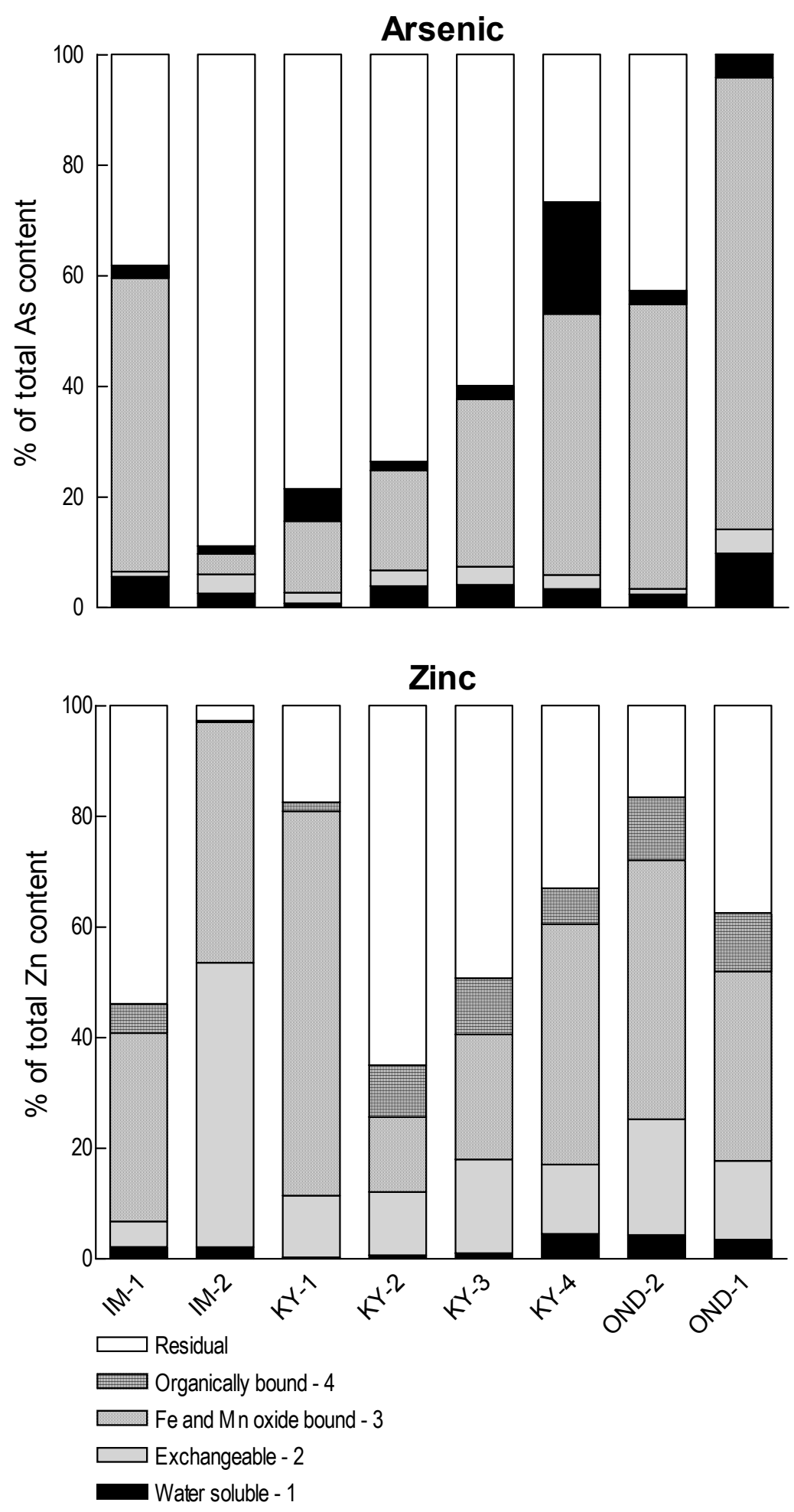

Fig. 2. Geochemical distribution of $\mathrm{As}$ and $\mathrm{Zn}$ in the impoundment materials, the Kyjov brook and the Ondava River sediments evaluated by sequential extraction.

Obr. 2. Distribúcia As a Zn v materiáloch odkaliska a v sedimentoch toku Kyjov a rieky Ondava získaná sekvenčnou extrakciou. 
spectively. The plant species Phragmites australis contained As concentrations ranging from 21.59 to $546.4 \mathrm{mg} \mathrm{kg}^{-1}$ and from 0.68 to $5.54 \mathrm{mg} \mathrm{kg}^{-1}$ in the roots and shoots, respectively. Concentrations of As in both Typha latifolia and Phragmites australis growing in the polluted area were on the average 10 to 100 times higher than those in the tissues of both plant species growing in the relatively non-polluted area of the Vel'ký Draždiak lake (Bratislava) (Tab. $4)$. This difference indicates an enhanced bioavailability of arsenic in the area with high total As contents in the impoundment materials. Roots of both species analyzed tended to accumulate higher levels of arsenic than shoots (Tab. 4). Zinc was accumulated also to greater extent in the roots of both plant species than in the shoots (mean root $\mathrm{Zn}$ concentra- tions were 72.4 and $136.9 \mathrm{mg} \mathrm{kg}^{-1}$ versus shoots: 23.9 and $21.5 \mathrm{mg} \mathrm{kg}^{-1}$ for Typha latifolia and Phragmites australis, respectively). These results are similar to those by Dushenko et al. (1995), reporting mean root As concentration $232 \mathrm{mg} \mathrm{kg}$ and shoots $17.2 \mathrm{mg} \mathrm{kg}^{-1}$ for Typha latifolia growing at the sites highly polluted with arsenic. Also in agreement with results of this study, Stoltz, Greger (2002) and Windham et al. (2003) have observed differences between root and shoot concentrations of As and $\mathrm{Zn}$ for Phragmites australis, being much greater in the roots than in the shoots. Thus, both plant species have restricted translocation of elements to the shoot, i.e. they are mostly root accumulators.

$\mathrm{T} \mathrm{a} \mathrm{b} \mathrm{le} \mathrm{4.} \mathrm{Total} \mathrm{As} \mathrm{and} \mathrm{Zn}$ contents $\left[\mathrm{mg} \mathrm{kg}^{-1}\right]$ in plants from the impoundment and reference non-polluted area.

$\mathrm{T}$ a b u l' k a 4. Celkové koncentrácie As a $\mathrm{Zn}\left[\mathrm{mg} \mathrm{kg}^{-1}\right]$ v rastlinách z odkaliska a z referenčnej neznečistenej oblasti.

\begin{tabular}{lcccc}
\hline & \multicolumn{2}{c}{ Typha latifolia } & \multicolumn{2}{c}{ Phragmites australis } \\
& Roots & Shoots & Roots & Shoots \\
\hline Number of samples & \multicolumn{2}{c}{ Arsenic $\left[\mathrm{mg} \mathrm{kg}^{-1}\right]$} \\
Range & $18.73-976$ & 8 & 5 & 5 \\
Mean & 216.2 & $0.42-635$ & $21.59-546.4$ & $0.68-5.54$ \\
Standard deviation & 340.5 & 81.86 & 136.7 & 2.69 \\
Non-polluted area & 3.27 & 223.5 & 229.4 & 0.28 \\
\hline & 0.66 & 11.48 & 5 \\
\hline Number of samples & 8 & \multicolumn{3}{c}{ Zinc $\left[\mathrm{mg} \mathrm{kg}^{-1}\right]$} \\
Range & $26.9-122.1$ & 8 & 5 & $10.8-32.7$ \\
Mean & 72.4 & $14.6-34.0$ & $24.7-519.1$ & 21.5 \\
Standard deviation & 41.8 & 23.9 & 136.9 & 8.39 \\
Non-polluted area & 21.8 & 5.66 & 214.3 & 12.9 \\
\hline
\end{tabular}

\section{Conclusions}

This study has shown that As in the impoundment is transported, gradually contaminating the Kyjov brook and finally the Ondava River, one of the most important fluvial courses in the region. The high As contents are observed in impoundment materials as well as in stream sediments and surface waters, the latter being diminished as a function of the distance from the impoundment. Most of the sediment and surface water samples at this site greatly exceed any environmental and health standards for As. The results indicate that As and $\mathrm{Zn}$ closely associate with $\mathrm{Fe}, \mathrm{Mn}$, and $\mathrm{Al}$ oxides in these sediments. Plants (Typha latifolia and Phragmites australis) sampled in different sites of the impoundment show elevated As and Zn con- tents compared with those found in the same plants growing in the relatively non-polluted area.

Much of the As in the sediment samples remains in sparingly soluble solid phases. Outside of the residual fraction, As was primarily associated with $\mathrm{Fe}$ and $\mathrm{Mn}$ oxides. The most mobile and bioavailable As (water soluble + exchangeable) represented on average $6.62 \%$ of the total As content. However, expressed in concentration levels $\left(\mathrm{mg} \mathrm{kg}^{-1}\right)$, these relatively low percentages for the 3 most contaminated sediments with As exceed limit values given by the environmental standards. The water solubility of As (\% of total As content) in stream sediments and impoundment materials was reduced with increasing content of $\mathrm{NH}_{4}$-oxalate extractable $\mathrm{Al}, \mathrm{Fe}$ and $\mathrm{Mn}$. For zinc, besides the residual fraction (mean $34 \%$ of total $\mathrm{Zn}$ content), the most dominant fractions are $\mathrm{Fe} / \mathrm{Mn}$ oxide and exchange- 
able fractions with mean values of 38.5 and $18 \%$, respectively.

Thus, the studied impoundment affects negatively the catchment area of the Kyjov brook and the Ondava River, polluting both streams with As. This study shows the need for further investigation and an environmental risk assessment in the area. Acknowledgments. This study was financially supported by the Slovak Grant Agency project VEGA no. $1 / 2037 / 05$ and $1 / 0312 / 08$.

\section{REFERENCES}

ADAMIEC E., HELIOS-RYBICKA E., 2002: Distribution of pollutants in the Odra river system. Part V. Assessment of total and mobile heavy metals content in the suspended matter and sediments of the Odra river system and recommendations for river chemical monitoring. Polish J. Environ. Stud., 11, 675-688.

ALLOWAY B.J., AYRES D.C., 1993: Chemical principles of environmental pollution. $1^{\text {st }}$ edition. Blackie Academic \& Professional, an imprint of Chapman \& Hall, London, $291 \mathrm{pp}$.

ANON, 2005: Act of the Government of the Slovak Republic from 21 June 2005 on demand to quality and qualitative targets of surface water and limit values of contamination indicators of waste water and specific water (in Slovak). Law Collection No. 296, pp. 2928-2991.

BIRD G., BREWER P.A., MACKLIN M.G., BALTEANU D., DRIGA B., SERBAN M., ZAHARIA S., 2003: The solid state partitioning of contaminant metals and As in river channel sediments of the mining affected Tisa drainage basin, northwestern Romania and eastern Hungary. Appl. Geochem., 18, 1583-1595.

CAI Y., CABRERA J.C., GEORGIADIS M., JAYACHANDRAN K., 2002: Assessment of arsenic mobility in the soils of some golf courses in South Florida. Sci. Total Environ., 291, 123-134.

CAO X., MA L.Q., 2004: Effects of compost and phosphate on plant arsenic accumulation from soils near pressure-treated wood. Environ. Pollut., 132, 435-442.

CHEN M., MA L.Q., HARRIS W.G., 2002: Arsenic concentrations in Florida surface soils: Influence of soil type and properties. Soil Sci. Soc. Am. J., 66, 632-604.

CHUAN M.C., SHU G.Y., LIU J.C., 1996: Solubility of heavy metals in a contaminated soil: effects of redox potential and pH. Water Air Soil Pollut., 90, 543-556.

CRECELIUS E.A., BOTHNER M.H., CARPENTER R., 1975: Geochemistries of arsenic, antimony, mercury, and related elements in sediments of puget sound. Environ. Sci. Technol., 9, 325-333.

DUSHENKO W.T., BRIGHT D.A., REIMER K.J., 1995: Arsenic bioaccumulation and toxicity in aquatic macrophytes exposed to gold-mine effluent: relationships with environmental partitioning, metal uptake and nutrients. Aquatic Bot., 50, 141-158.

FERGUSSON J.E., 1990: The heavy elements. Chemistry, environmental impact and health effects. Pergamon Press, Oxford.

FRITZSCHE A., DIENEMANN H., DUDEL E.G., 2006: Arsenic fixation on iron-hydroxide-rich and plant litter- containing sediments in natural environments. Environ. Geol., 51, 133-142.

GANNE P., CAPPUYNS V., VERVOORT A., BUVÉ L., SWENNEN R., 2006: Leachability of heavy metals and arsenic from slags of metal extraction industry at Angleur (eastern Belgium). Sci. Total Environ., 356, 69-85.

GURRIERI J.T., 1998: Distribution of metals in water and sediment and effects on aquatic biota in the upper Stillwater River basin, Montana. J. Geochem. Explor., 64, 83-100.

HICKEY M.G., KITTRICK J.A., 1984: Chemical partitioning of cadmium, copper, nickel and zinc in soils and sediments containing high levels of heavy metals. J. Environ. Qual., 13, 372-376.

HILLER E., VESELSKÁ V., MAJZLAN J., 2007: Arsenic mobility in stream sediments and impoundment material as evaluated by column and batch experiments. J. Hydrol. Hydromech., 55, 223-235.

HUDSON-EDWARDS K.A., HOUGHTON S.L., OSBORN A., 2004: Extraction and analysis of arsenic in soils and sediments. Trends Anal. Chem., 23, 745-752.

JAIN C.K., 2004: Metal fractionation study on bed sediments of River Yamuna, India. Water Res., 38, 569-578.

JURKOVIČ L', KORDÍK J., SLANINKA I., 2006: Geochemical study of arsenic mobility in secondarily influenced Kyjov brook and Ondava river (Eastern Slovakia). Slovak Geol. Mag., 12, 31-38.

KAVANAGH P.J., FARAGO M.E., THORNTON I., BRAMAN R.S., 1997: Bioavailability of arsenic in soil and mine wastes of the Tamar valley, SW England. Chem. Speciat. Bioavailab., 93, 77-81.

KORDÍK J., SLANINKA I., 2001: Map of the natural water quality at a scale $1: 50$ 000. (In Slovak.) Final report. In: Puchnerová et. al. (Eds.), Investigation of natural resources in relation to the environment (Tibreg and surroundings), geological factors of the environment. GEOCOMPLEX Bratislava, State Geological Institute of Dionyz Stur Bratislava, $64 \mathrm{p}$.

KOVÁČ M., 2000: Geodynamic, paleogeographic and structural development of the Carpathian-Pannonian region during the Miocene: a new view on the Neogene basins of the Slovakia. (In Slovak.) VEDA, Bratislava, 204 pp.

LIN J.G., CHEN S.Y., 1998: The relationship between adsorption of heavy metal and organic matter in river sediments. Environ. Int., 24, 345-352.

LINTNEROVÁ O., ŠOTTNÍK P., ŠOLTES S., 2006: Dissolved matter and suspended solids in the Smolník Creek polluted by acid mine drainage (Slovakia). Geol. Carpath., 57, 311-324.

MATERA V., HECHO I.L., 2001: Arsenic behavior in contaminated soils: Mobility and speciation. In: Selim, H.M., Sparks, D.L. (Eds.), Heavy metals release in soils. CRC Press, Boca Raton, 207-235 pp.

MCKEAGUE J.A., BRYDON J.E., MILES N.M., 1971: Differentation of forms of extractable iron and aluminum in soils. Soil Sci. Soc. Am. Proc., 35, 33-38.

NIREL P.M.V., MOREL F.M.M., 1990: Pitfalls of sequential extractions. Water Res., 24, 1055-1056.

PAGNANELLI F., MOSCARDINI E., GIULIANO V., TORO L., 2004: Sequential extraction of heavy metals in river sediments of an abandoned pyrite mining area: pollution detection and affinity series. Environ. Pollut., 132, 189-201.

QUEVAUVILLER P., 1998: Operationally defined extraction procedures for soil and sediment analysis. I. Standardization. Trends Anal. Chem., 17, 289-298. 
Arsenic and zinc in impoundment materials and related stream sediments from a polluted area in Eastern Slovakia: distribution,...

RAMOS L., HERNANDEZ L.M., GONZALEZ M.J., 1994: Sequential fractionation of copper, lead, cadmium and zinc in soils from Donana National Park. J. Environ. Qual., 23, $50-57$.

REIMANN C., de CARITAT P., 1998: Chemical elements in the environment. Springer-Verlag, New York.

RENDELL P.S., BATLEY G.E., CAMERUN A.J., 1980: Adsorption as a control of metal concentrations in sediment extracts. Environ. Sci. Technol., 14, 314-318.

ROMERO L., ALONSO H., CAMPANO P., FANFANI L., CIDU R., DADEA C., KEEGAN T., THORNTON I., FARAGO M., 2003: Arsenic enrichment in waters and sediments of the Rio Loa (Second Region, Chile). Appl. Geochem., 18, 1399-1416.

RUDINEC R., 1978: Paleogeographical, lithofacial and tectogenetic development of the neogene in Eastern Slovakia and its relation to volcanism and deep tectonics. Geol. Zbor. Geol. Carp., 29, 225-240.

SAKAN S., GRŽETIĆ I., ĐORĐEVIĆ D., 2007: Distribution and fractionation of heavy metals in the Tisa (Tisza) river sediments. Env. Sci. Pollut. Res., 14, 229-236.

SMEDLEY P.L., KINNIBURGH D.G., 2002: A review of the source, behaviour and distribution of arsenic in natural waters. Appl. Geochem., 17, 517-568.

SOTÁK J., PERESZLÉNYI M., MARSCHALKO R., MILIČKA J., STÁREK D., 2001: Sedimentology and hydrocarbon habitat of the submarine fan deposits of the Central Carpathian Paleogene Basin, (NE Slovakia). Mar. Petrol. Geol., 18, 87-114.

STOLTZ E., GREGER M., 2002: Accumulation properties of $\mathrm{As}, \mathrm{Cd}, \mathrm{Cu}, \mathrm{Pb}$ and $\mathrm{Zn}$ by four wetland plant species growing on submerged mine tailings. Environ. Exper. Bot., 47, 271-280.

TACK F.M., CALLEWAERT O.W.J.J., VERLOO M.G., 1996: Metal solubility as a function of $\mathrm{pH}$ in a contaminated, dredged sediment affected by oxidation. Environ. Pollut., 91, 199-208.

TIGHE M., ASHLEY P., LOCKWOOD P., WILSON S., 2005: Soil, water, and pasture enrichment of antimony and arsenic within a coastal floodplain system. Sci. Total Environ., 347, 175-186.

VISSER W.J.F., 1995: Contaminated land policies in Europe. Chem. Ind., 13, 496-499.

VOJTEKOVÁ V., KRAKOVSKÁ E., 2006: Frakcionačná analýza sedimentov - limitácie selektivity sekvenčného lúhovania. Chem. Listy, 100, 1096-1104.

VOLAUFOVÁ L., LANGHAMMER J., Specific pollution of surface water and sediments in the Klabava River basin. J. Hydrol. Hydromech., 55, 2007, 2 122-134.

VROM, 2000: Circular on target values and intervention values for soil remediation: DBO/1999226863. Netherlands Government Gazette, 39, 1-11.

WINDHAM L., WEIS J.S., WEIS P., 2003: Uptake and distribution of metals in two dominant salt marsh macrophytes, Spartina alterniflora (cordgrass) and Phragmites australis (common reed). Estuar. Coast. Shelf Sci., 56, 63-72.

XU J., THORNTON I., 1985: Arsenic in garden soils and vegetable crops in Cornwall, England: implications for human health. Environ. Geochem. Health, 7, 131-133.

WWW.ZBIERKA.SK. Legislation No. 188/2003 of the Ministry of Agriculture, Slovak Republic on the application of sewage sludges and bottom sediments into the soil. (In Slo- vak.) CIURA EDITION, spol. s.r.o, 1062-1076. Accsess date: $18^{\text {th }}$ of december 2008 .

Received 27. October 2008

Review accepted 19. February 2009

\section{ARZÉN A ZINOK V MATERIÁLOCH ODKALISKA A V RIEČNYCH SEDIMENTOCH ZO ZNEČISTENEJ OBLASTI NA VÝCHODNOM SLOVENSKU: DISTRIBÚCIA, MOBILITA A KVALITA VÔD}

Michal Jankulár, Edgar Hiller, L'ubomír Jurkovič, Veronika Veselská, Juraj Majzlan

Referát sa zaoberá problematikou znečistenia povrchových vôd a riečnych sedimentov toku Kyjov a rieky Ondava potenciálne toxickými prvkami - arzénom a zinkom, ktorých zdrojom sú vody vytekajúce z odkaliska nad obcou Poša (východné Slovensko). Stanovili sa celkové koncentrácie As a Zn, ako aj mnohé d'alšie fyzikálno-chemické a mineralogické charakteristiky reprezentatívnych vzoriek materiálov uložených na odkalisku, riečnych sedimentov a povrchových vôd (obr. 1). Okrem toho bola skúmaná aj distribúcia a geochemické formy vystupovania As a Zn v pevných materiáloch odkaliska a riečnych sedimentoch pomocou pät'krokovej sekvenčnej extrakcie (tab. 1). Nakoniec sa analyzovali aj koncentrácie As a Zn vo vzorkách dvoch rastlinných druhov (Typha latifolia a Phragmites australis), ktoré majú na odkalisku najväčšie zastúpenie.

Dosiahnuté výsledky poukazujú na výrazné znečistenie všetkých sledovaných zložiek arzénom, hoci $\mathrm{v}$ prípade $\mathrm{Zn}$ sa prejavilo znečistenie len $\mathrm{v}$ materiáloch uložených na odkalisku (tab. 2 a 3). Výsledky zo sekvenčnej extrakcie odkaliskových materiálov a riečnych sedimentov ukázali, že najväčšie riziko pre životné prostredie predstavujú vzorky s najvyšším celkovým obsahom arzénu, ked’že z nich sa uvol’nili aj najvyššie absolútne množstvá As v l'ahko dostupnej, vodorozpustnej a vymenitel'nej forme (od 37 do $116 \mathrm{mg} \mathrm{kg}^{-1}$ ), ktoré prekračujú limitné hodnoty pre tento prvok uvádzané napr. Holandskou normou. V prípade obidvoch prvkov bol významný 3 . krok sekvenčnej extrakcie, ktorý vyjadruje viazanie As a $\mathrm{Zn}$ na oxyhydroxidy Fe a Mn (obr. 2). $\mathrm{V}$ tab. 4 sú uvedené koncentrácie As a Zn v koreňoch a nadzemných častiach dvoch rastlinných druhov dominantne rastúcich na odkalisku. Všeobecne možno konštatovat', že korene akumulovali As a Zn lepšie ako nadzemné časti týchto rastlinných druhov. Navyše, rastliny z odkaliska obsahovali 10- až 100-násobne vyššie koncentrácie As ako tie isté rastliny odobraté z relatívne neznečistenej oblasti. Táto skutočnost' poukazuje na zvýšenú bioprístupnost' arzénu na skúmanom odkalisku, ktoré je typické vysokými obsahmi celkového As v uložených materiáloch. 